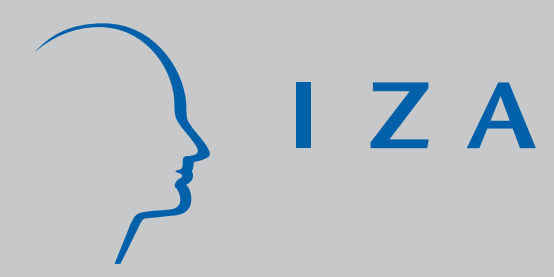

IZA DP No. 1739

The Origins of Intergenerational Associations:

Lessons from Swedish Adoption Data

Anders Björklund

Mikael Lindahl

Erik Plug

September 2005 


\title{
The Origins of Intergenerational Associations: Lessons from Swedish Adoption Data
}

\author{
Anders Björklund \\ SOFI, Stockholm University \\ and IZA Bonn \\ Mikael Lindahl \\ SOFI, Stockholm University \\ and IZA Bonn \\ Erik Plug \\ University of Amsterdam, Tinbergen Institute \\ and IZA Bonn
}

\section{Discussion Paper No. 1739 \\ September 2005}

\author{
IZA \\ P.O. Box 7240 \\ 53072 Bonn \\ Germany \\ Phone: +49-228-3894-0 \\ Fax: +49-228-3894-180 \\ Email: iza@iza.org
}

Any opinions expressed here are those of the author(s) and not those of the institute. Research disseminated by IZA may include views on policy, but the institute itself takes no institutional policy positions.

The Institute for the Study of Labor (IZA) in Bonn is a local and virtual international research center and a place of communication between science, politics and business. IZA is an independent nonprofit company supported by Deutsche Post World Net. The center is associated with the University of Bonn and offers a stimulating research environment through its research networks, research support, and visitors and doctoral programs. IZA engages in (i) original and internationally competitive research in all fields of labor economics, (ii) development of policy concepts, and (iii) dissemination of research results and concepts to the interested public.

IZA Discussion Papers often represent preliminary work and are circulated to encourage discussion. Citation of such a paper should account for its provisional character. A revised version may be available directly from the author. 
IZA Discussion Paper No. 1739

September 2005

\section{ABSTRACT}

\section{The Origins of Intergenerational Associations: Lessons from Swedish Adoption Data*}

We use unique Swedish data to estimate intergenerational associations between adoptees and their biological and adoptive parents. We argue that the impact from biological parents captures broad pre-birth factors, including genes and prenatal environment, and the impact from adoptive parents represents broad post-birth factors, such as childhood environment, for the intergenerational association in education and income. We find that both pre- and postbirth factors contribute to intergenerational transmissions, and that pre-birth factors are more important for mother's education and less important for father's income. We also find some evidence for a positive interaction effect between post-birth environment and pre-birth factors.

JEL Classification: $\quad$ I20, J30 J62

Keywords: intergenerational mobility, nature and nurture, income, education, adoption data

Corresponding author:

Anders Björklund

Swedish Institute for Social Research (SOFI)

Stockholm University

SE-10691 Stockholm

Sweden

Email: Anders.Bjorklund@sofi.su.se

\footnotetext{
* We are very grateful for detailed and constructive comments by Lawrence Katz, Edward Glaeser. We also thank Helena Holmlund, Sandy Jencks and numerous seminar and conference participants for useful suggestions. Financial support from the Swedish Council for Working Life and Social Research (FAS) is gratefully acknowledged.
} 


\section{INTRODUCTION}

A burgeoning literature examines the empirical association between the income and education of parents and their children. ${ }^{1}$ No doubt, this new literature offers several interesting insights, for example some notable cross-national differences in the magnitude of intergenerational income elasticities. But it is almost an understatement to say that researchers have not yet been able to uncover much about the mechanisms underlying these empirical associations. Thus, there is a long way to go until research can give constructive guidelines for policies to remedy the impact of family background on socioeconomic status during adulthood.

One approach to learning more about these mechanisms is to estimate intergenerational associations for parents and children who are related through adoption and compare these estimates with those for samples of parents and children who are representative of the whole population. Recently this approach has been taken by Sacerdote [2000, 2002, 2004], Plug and Vijverberg [2003, 2004], Plug [2004] and Björklund, Lindahl and Plug [2004]. ${ }^{2}$ They find weaker intergenerational associations for adoptive families, suggesting that factors that are shared by own-birth children ${ }^{3}$ and their parents but not by adoptees and their adoptive parents contribute to the empirical associations.

In this study, we extend the intergenerational analysis of adoption data. We can do so thanks to a unique Swedish data set that has a number of advantages compared to the ones that previous researchers have had at their disposal. Most important, we have

\footnotetext{
1 See Solon [1999] and a symposium in the Journal of Economic Perspectives (Summer 2002) for surveys.

2 See also Scarr and Weinberg [1978], and Das and Sjogren [2002] for work along these lines.

3 We use the concept own-birth child for the case when a child was reared by its biological parents.
} 
information about adopted children's biological as well as adoptive parents. Thus we can examine the relative importance of, on the one hand, genetics and pre-natal environments and, on the other hand, post-birth childhood environments to child outcomes. Another advantage of our data set is its size. It contains all children who were born in Sweden 1962-1966 and formally adopted by both parents by a public court decision, in all over 5000 persons. The fact that the adoptees were born in Sweden and thus not a mix of Sweden-born and foreign-born adoptees is another advantage of our data.

Our overall finding is that adopted children's education and income are positively associated with both their biological parents’ and their adoptive parents' education and income. The intergenerational education association with biological mothers tend to be even somewhat stronger than for adoptive mothers. For fathers, the opposite result holds for earnings, whereas biological and adoptive fathers are equally important regarding education. We also find slightly larger intergenerational education coefficients for biological mothers than for biological fathers. Models that incorporate interaction effects between adoptive and biological parents tend to yield positive interaction coefficients although not always statistically significant different zero.

The paper proceeds in section II with a presentation of the intergenerational models that we estimate with our data. Section III presents the institutional setting of adoptions in Sweden in 1962-1966 and the administrative data that we use in the analysis. We report our basic results in section IV, a number of robustness tests in section V, and finally we discuss our main findings in section VI. 


\section{INTERGENERATIONAL TRANSMISSION MODELS}

\section{A. LINEAR MODELS}

In recent intergenerational research, the prototypical model used by economists can be expressed as:

$$
Y_{j}^{b c}=\beta_{0}+\beta_{1} Y_{j}^{b p}+v_{j}^{b c}
$$

where $Y$ denotes the logarithm of long-run income or a measure of educational attainment at adult age; subscript $j$ indexes the family in which the child is born and raised;

superscripts $b c$ and $b p$ denote child and parent; ${ }^{4}$ and $v_{j}^{b c}$ is a child-specific characteristic uncorrelated with $Y_{j}^{b p}$. The estimated intergenerational coefficient $\beta_{1}$ measures the strength of the intergenerational association and represents the combined effect of many different mechanisms, including the effects that come from genetic inheritance, prenatal environment and the environment in which the child grew up.

Our data on adoptees and their biological and adoptive parents allow us to decompose the estimated intergenerational coefficient $\beta_{1}$ into two components --one component that measures the contribution of genetics and prenatal environment (pre-birth factors) and the other one that measures the contribution of post-birth environment on the outcomes of children. We model the transmission of an outcome from the biological parent $b p$ and the adoptive parent ap to the adopted child $a c$ born in family $j$ and adopted and reared in family $i$

$$
Y_{i}^{a c}=\alpha_{0}+\alpha_{1} Y_{j}^{b p}+\alpha_{2} Y_{i}^{a p}+v_{i}^{a c}
$$

\footnotetext{
4 Most studies - e.g. those that rely on U.S. PSID and NLSY data - have used rearing parents, including biological, step and adoptive parents. We use the notation $b p$ for expositional convenience.
} 
where $v_{i}^{a c}$ represents unobserved child-specific characteristics uncorrelated with $Y_{j}^{b p}$ and $Y_{i}^{a p}$. It is important to note that the parental $Y$ 's do not only capture the parental characteristics but also everything else that is correlated with it. This means that we estimate parameters that capture broad pre-birth factors $\left(Y_{j}^{b p}\right)$ and broad post-birth environment ( $Y_{i}^{a p}$ ), and that we do not consider $\alpha_{1}$ and $\alpha_{2}$ as the causal impact of the parents' $Y$. Pre-birth factors include genetic and prenatal environmental factors. Postbirth factors include, for example, the impact that $Y$ has on the quality and quantity of time, goods and money parents devote to their children.

We can further separate pre-birth factors into impacts of genetic and pre-natal environmental factors by estimating the effects of biological mothers and fathers in separate regressions. Assuming that genetic transfers that come from the biological mother and father are equally important, and that the father's behaviour does not affect the child's pre-natal conditions in the womb, we can interpret the impact of father's characteristics as an estimate of genetic factors and the difference in impacts between biological mother and father's characteristic as an estimate of the impact of pre-natal environmental factors.

The procedure to link the prototypical mobility model in (1) to the adoption model in (2) is relatively simple. For children who are not adopted but born and raised in the same family $j$, we know that $Y_{i}^{a p}$ and $Y_{j}^{b p}$ are identical. If we replace $Y_{i}^{a p}$ with $Y_{j}^{b p}$, model (2) collapses to model (1) where the intergenerational transmission coefficients $\beta_{1}$ and $\alpha_{1}+\alpha_{2}$ are identical. Two considerations are of interest here. The first one relates to whether or not we can infer the relative contributions of pre- and post-birth factors for a 
representative Swedish child from a sample of adoptees. The second one relates to whether or not we can use adoptees to separate pre- from post-birth contributions.

To compare $\beta_{1}$ and $\alpha_{1}+\alpha_{2}$ we need to assume that adopted and own-birth children and their parents are randomly drawn from one particular distribution of children and parents. ${ }^{5}$ For adopted children, however, $Y_{i}^{a p}$ and $Y_{j}^{b p}$ are distinctively different. Then how do the estimates for own-birth children compare to those obtained for adoptees? Investigating this is easier said than done. Whereas the estimates for own-birth children come from a representative sample, the adoption results come from a sample of children with, on average, disadvantaged pre-birth but favorable post-birth backgrounds. These opposite sources of selection make it difficult - if not impossible - to come up with a sample of own-birth children that is comparable to our sample of adoptees. We deal with this by comparing own-birth children to the adoptees in two different ways. First, we compare adoptees with own-birth children who start their lives under very similar conditions as adoptees. Second, we compare adoptees with another sample of own-birth children who are reared in similar environments as the adoptees. Different samples are made comparable through propensity score matching and subsampling.

To interpret $\alpha_{1}$ and $\alpha_{2}$ as pre- and post-birth contributions, respectively, we need to make three additional assumptions. First, adoptees are randomly assigned to adoptive families, or in case of selective placement, the assignment is done on variables that we as researchers observe. Second, children move to their adoptive parents immediately at

\footnotetext{
5 Previous adoption studies (such as Plug [2004] and Sacerdote [2004]) lacked data on biological parents of adoptees, and could therefore only estimate the impact of post-birth factors. They could only indirectly infer the impact of pre-birth factors by taking the difference between the intergenerational estimate for own-birth children and the estimate of the impact of post-birth factors. This means that they had to assume that $\alpha_{1}=\beta_{1}-\alpha_{2}$. However, since adoptees are different compared to own-birth children on a number of dimensions, it is not a priori clear that this assumption holds. In this paper we estimate both $\alpha_{1}$ and $\alpha_{2}$ directly.
} 
birth. And third, interaction effects between genes and environment are absent. Whereas the first two problems are dealt with in the sensitivity analysis section, we now turn to genes-environment interactions.

\section{B. NON-LINEAR MODELS}

Interaction between genes and environment is an issue that has been given much attention in the recent literature. ${ }^{6}$ Empirical tests, however, are only indirect and there is hardly any consensus about the presence of such interactions. ${ }^{7}$ Our data set is especially suitable to test for such interactions. We have information on adoptees' adoptive and biological parents for a very large number making it possible to estimate interaction terms with reasonable precision. We can modify model (2) to account for interaction effects of pre- and post-birth factors to

$$
Y_{i}^{a c}=\alpha_{0}+\alpha_{1} Y_{j}^{b p}+\alpha_{2} Y_{i}^{a p}+\alpha_{3} Y_{j}^{b p} Y_{i}^{a p}+u_{i}^{a c}
$$

The interaction coefficient $\alpha_{3}$ is positive if children with beneficial pre-birth background benefit relatively more from a good post-birth environment, which would indicate that genetic and environmental factors are complements in the production of life

\footnotetext{
6 For discussions, see Cunha et al. [2005] and Ridley [2003]. Turkheimer et al. [2003], an often cited study, use a little over 100 monozygotic and 200 dizygotic twin pairs and variance decomposition techniques to estimate how much genes and environment can explain the variation in IQ among 7 year old children, at different levels of socioeconomic background for their parents. They find genetic (shared environmental) effects to be more (less) important the higher the childrens' socioeconomic backgrounds. 7 Plomin, DeFries and Fuller [1988] survey genotype-environment interaction studies in behavioral genetics. They find few statistically significant interactions and state that interactions "are easily posed but rarely documented.” Björklund, Jäntti and Solon [2005] use sibling correlations for nine sibling types to decompose earnings variation into genetic and environmental components. When they extend a conventional model with a parameter that reflects interaction between genes and environment they get a positive but insignificant estimate. Note that, while they also are using Swedish data, their approach are different from ours. First, they use sibling correlations, and we use intergenerational data. Second, they apply the variance decomposition approach, whereas we estimate regression coefficients telling what a unit of parental education implies for offspring's education and how a log point of paternal income (earnings) is related to offspring's log income (earnings). Third, they do not analyze education.
} 
success for the child. The corresponding model for parent and child in a non-adoption family, where $Y_{i}^{a p}$ and $Y_{j}^{b p}$ are identical, is written as

$$
Y_{j}^{b c}=\beta_{0}+\beta_{1} Y_{j}^{b p}+\beta_{2}\left(Y_{j}^{b p}\right)^{2}+u_{j}^{b c}
$$

Apart from distributional considerations, we do not want to infer interactions from a positive $\beta_{2}$. If, for example, quadratic effects are present in (3), $\beta_{2}$ would capture both interaction and quadratic effects. ${ }^{8}$

\section{INSTITUTIONS AND DATA ${ }^{9}$}

We use administrative register data from Statistics Sweden on all legal adoptions, i.e., adoptions decided by public court and notified in the Swedish population register. In particular, our data set contains all persons who were born in Sweden between 1962 and 1966 and adopted by both parents. To show the usefulness of this data set, we start this section by describing the Swedish adoption institutions during this period of time. Then we describe the data set and the variables in some detail.

\section{A. ADOPTIONS IN SWEDEN 1962 - 1966}

The basic principle of Swedish adoption law has always been that an adoption should be "in the best interests of the child". This means, for example, that the decision whether an adoption should take place and the choice of adoptive parents should be motivated by

8 Note that an alternative interaction term $\sqrt{Y_{i}^{a p}} \cdot \sqrt{Y_{j}^{b p}}$ in model (3) would lead to the linear model in (1). So the result that interactions in model (3) lead to a non-linear model (4) is by no means a general one.

$9 \quad$ See Björklund, Lindahl and Plug [2004] for more details and sources. 
concern of the child and not of the couple that wants to adopt. Economic compensation between the adoptive and the biological parents was not allowed. Because the period we consider was characterized as one with “excess demand” from prospective adoptive parents, payments to biological parents would probably have existed if allowed. An adopted child got the same legal status, e.g., with respect to inheritance, as a biological child. Further, all formal connections with the biological parents were broken.

A social authority was responsible for the process. Thus, mothers (and fathers) who wanted to adopt away a child as well as families who wanted to adopt should contact this authority. The legal adoption decision was taken by public court after being advised by the social authority.

The vast majority of adoptions took place at an early age of the child. In a typical case, an unmarried pregnant woman considered adoption and therefore contacted the social authority. But the mother could not decide to adopt away a child until she had recovered from the delivery. The new-born child was therefore initially placed at a special nursery home. An unmarried biological father had no formal say in the adoption decision, but should be contacted on the issue and allowed to give his opinion. Quite often, however, the father was unknown. The population register we use identifies 92 percent of the biological mothers and 58 percent of the biological fathers.

The child was first placed in a prospective adoptive family on a trial basis as a foster child. Placements were recommended to occur before age 6 months. If the trial period lasting some 3-6 months - turned out well, the next step for the prospective adoptive parents was to apply to the court for a legal adoption decision. The formal process by the 
court could take several months so the adopted child could have spent quite long time with its new parents when the adoption was finally formalized.

In general, the biological mother was young, unmarried and poor. Our Table I (see below), reporting descriptive statistics for all cases when both biological parents to adopted children in Sweden born 1962-1966 were known, shows that both biological mothers and fathers were younger than non-adopted children’s parents. Nonetheless, there is a substantial age variation among biological parents and only 32 percent of the mothers and 12 percent of the fathers were teenagers when the child was born.

Low income was a common reason to leave a child for adoption and lower social classes were clearly overrepresented among biological mothers. One should note, though, that socio-economic status before age 30 does not strongly correlate with long-run status. Further, "shame" was also a common reason for adoption. Thus, although we have reason to believe that most mothers had low socio-economic status also in a long-run perspective, they were not necessarily a very homogenous group in this respect.

The responsible social worker, assigned by the social authority, should undertake a careful investigation of prospective adoptive parents. The guidelines for adoptions emphasized that, given a reasonable "stable" situation, economic resources and social status were not most important. Although not a formal requirement, it was expected that the mother could stay home to care for the child. The guidelines said that good adoptive parents should be tolerant, since an adopted child could get into problems and maybe not meet the expectations of its parents. "Normal people” were considered the best adoptive parents. Nonetheless, due to these considerations, one would expect adoptive parents to be under-represented among families with low socio-economic status. 
The law required that the adoptive parents should be 25 years of age. There was no upper age limit but the adoptive parents were supposed to be young enough to be able to be the biological parents of the child. There was no requirement about the duration of the marriage. But other requirements made it unlikely that newly married couples would be able to adopt a child. For example, the social worker was supposed to find out that the prospective adoptive parents would not be able to get own biological children.

A crucial issue in adoption research is whether there likely is selective placement so that there is a positive correlation in important traits between biological and adoptive parents. Our data - see section V and Björklund, Lindahl and Plug [2004] for more details - confirm such a positive correlation in education and income. Bohman [1970], who studied adoption practices in Sweden, showed that the actual behaviour of social workers generated such patterns.

Although the adoption case described above was by far the most common one, there were also other cases. One case was when a foster child "grew into" the foster family so that the foster parents wanted to adopt the child. Step-parent adoptions were yet another kind of adoption, namely such when the spouse of one biological parent adopted the latter's child. Our data allow us to identify such cases; we found 6 cases and eliminated them. Adoptions could also take place within families, e.g., the parents of a young mother could adopt a child that would be their biological grandchild. Such cases would create severe problems for our study. However, they were very rare during our study period.

\section{III.B. THE DATA SET AND DESCRIPTIVE STATISTICS}


Because of the adoption process described above, the Swedish population register contains information about both adoptive and biological parents. From the population register, we also get access to the adopted children's siblings, both on their biological parents' side (our data distinguish between full and half siblings) and on their adoptive parents' side. On the latter side, there could be both siblings who also are adopted and siblings who are biological children of the adoptive parents. ${ }^{10}$

Further, we use education and tax registers to get information about parental characteristics and child outcomes at adult age. The 1970 census and the 1990 version of Statistics Sweden's special education register provide information about biological and adoptive parents' education. The 1970 Census, upon which the education register is built, contains detailed education information, which is available in terms of very detailed education classifications. We infer years of schooling and a university dummy from this information. ${ }^{11}$ We use tax-register data to get fathers' earnings and income for 1970 , 1975, 1980, 1985 and 1990. Earnings include income from work including selfemployment and sickness benefits. Income includes earnings, but also some taxable benefits like unemployment insurance and pensions as well as capital income and realized capital gains. The tax registers in turn are based on compulsory reports from employers, and the taxable benefits are similarly reported by the authorities responsible for the schemes. We use father's income averaged over a 20-year period running from

\footnotetext{
10 Our data tell us in what census the adoptee first lived with its adoptive parents, although the parents were not necessarily formal adoptive parents at this point of time due to the trial period and delay with the court's decision.

11 We use the education register dated 1990 to obtain parental education measures. If not available, we use the 1970 Census instead. The reason for doing so is that some parents were quite young in 1970 . The 1970 Census, upon which the education register is built, and the 1990 register contain identical educational level classifications. We assign the following years of schooling to seven educational levels: 7 for (old) primary school, 9 for (new) compulsory schooling, 11 for short high school, 12 for long high school, 14 for short university, 15.5 for long university, and 19 for Ph.D. University education is a dichotomous variable that indicates whether someone completed 15 or more years of schooling.
} 
1970 to $1990 .^{12}$ Since (due to the adoption guidelines in the early 1960s) adoptive mothers were expected not to work, we focus only on the intergenerational mobility effects of father's earnings and income. Our analysis thus follows the empirical literature on income mobility that focus on the impact of long-run income of fathers.

We measure children's outcome in 1999 when children are 33-37 years of age. At this age, children should have completed their school and their annual income is likely to measure long-run (or lifetime) income quite well with only a classical measurement error. This means that our intergenerational estimates will not suffer from so called life-cycle bias. ${ }^{13}$ Education information comes from the education register. ${ }^{14}$ Children's income and earnings data stem from the same administrative registers as the ones for parents.

The number of adopted children born in Sweden in 1962-1964 was about 1100 each year, and began to fall to 1000 in 1965 and 900 in $1966 .{ }^{15}$ The number of adoptees born in Sweden between 1962-1966 equals 5292. We work with a subsample of 2125 adopted children. The reduction of 3067 observations gives the impression that nonresponse is serious. Of the 3067 adoptees who fell outside the sample, about 500 observations were lost because of a set of age restrictions pertaining to the adopted child and adoptive

\footnotetext{
12 More specifically, we first exclude those observations in which annual income (or earnings) is missing, below 1000 dollars, or obtained when parents were younger than 30 or older than 60 . With annual income and earnings measures measured in logarithms, we then take averages.

13 Using U.S. data, Haider and Solon [2005] examine how intergenerational income estimates are affected by the age at which offspring's income is observed. They find that the bias is small when annual income is measured around age 35. Böhlmark and Lindquist [2005], who replicate and extend Haider and Solon [2005] on Swedish data, arrive at the same conclusion.

14 We use the maximum level achieved in the 1990, 1993, 1996 or 1999 education registers. For children and their parents we use the same transformation from levels to years.

15 With a falling number of children born in Sweden given up for adoption, the number of foreign born adoptees started to increase. For example, between 1962 and 1966 the number of international adoptions rose from 100 to 350 .
} 
parents, ${ }^{16} 135$ adoptees had no records on their own or adoptive parents educational classifications, and about 570 adoptees were eliminated because information on their biological mother was missing. The main problem exists with the adoptees’ biological fathers. Almost 2000 adoptees have biological fathers that are unknown. ${ }^{17}$ This leaves us with 2125 adoptees. The income analysis is based on fewer observations than the education analysis: about 150 (335) adoptees had annual income (earnings) values that were either missing or unrealistically small (less than the Swedish equivalent of a 1000 dollars).

Table I reports the means and standard deviations of the main variables in our analysis. We report these statistics for our adoptee sample and for a representative sample of all own-birth children required to have lived with both their biological parents in the fall 1970 census; the latter are drawn from a 20 percent random sample of all nonadopted children born in Sweden in 1962-1966. ${ }^{18}$ The table’s first panel shows that adopted children are quite similar to the random sample of same-aged own-birth children when it comes to the outcome variables. There are some small differences, however, and they consistently show that adopted children did slightly worse: years of schooling is about 0.4 years lower, the fraction with university education is 8 percentage points lower and earnings and income are 0.09 log points lower, compared to own-birth children.

\footnotetext{
16 We exclude those who (i) did not live with adoptive parents in the November 1970 census, (ii) died at age $<26$ (45 adoptees), (iii) had too young adoptive parents $(<25)$ or a too old adoptive parent (mother $>$ 47 or father $>66$ ).

17 The reduction of almost 2000 observations is substantial and may introduce sample selection bias. Later on in the paper we test whether the nonresponse is selective and muddling with our results. We find that this is not the case.

18 We start off with 108550 but work with 94079 children. We loose almost 14500 observations because of missing school classifications (more than 5200) and because of children that are raised in single parent families (more than 9200).
} 
The second panel compares the characteristics of own-birth and adopted children's birth parents. These differences are larger. Own-birth children's fathers have 0.73 more years of schooling than adopted children's fathers. The corresponding difference for mothers is 0.53 . University education is also more frequent among own-birth children's birth parents than among adopted children's birth parents. The earnings and income differentials are 0.29 log points for fathers. Further, adopted children's birth parents are about 3.5 years younger than own-birth children's biological parents. The fraction of teenage parents is also considerably higher among adopted children.

The third panel reports characteristics of adoptive parents. Comparing with adopted children's birth parents, we find quite substantial differences, especially for father's characteristics. Average years of schooling are 1.30 higher, incidence of university education is 0.13 higher, earnings and income are around 0.40 log points higher. The age differentials are as large as 8.8 years for fathers and 9.6 years for mothers. These age differentials, in turn, probably account for some of the earnings and income differentials. In our subsequent analysis we control for these age differentials.

These differences, which are all statistically significant, give the impression that children who are given up for adoption come from poorer families but are placed in wellto-do families. Despite mean differences between the parents, the standard deviations show that there is a considerable overlap between the three distributions. In some of the regressions using own-birth children and parents, we use samples of own-birth parents that are matched so as to mimic the adopted or biological parents. The matching procedure and the characteristics we match on are discussed in the next section. 


\section{BASIC RESULTS}

\section{IV.A. RESULTS FOR LINEAR MODELS}

Table II reports the intergenerational transmission estimates for education and income using a linear model. We run separate regressions on samples of own-birth and adopted children. In the first panel, we report the least square results of model (1) for education and income on the sample of own-birth children. All regressions include an intercept and individual controls for the child's gender, birth year and region of birth, and the respective parent's birth year. These estimates are not reported. The regressions are typical of estimations in the previous intergenerational mobility literature.

The estimated effects of parental schooling show - as expected - that higher educated parents raise their children's schooling years and university graduation chances. We find that the schooling impacts of both parents are equally important. The magnitude of these estimates suggests that four more years of parental schooling - of either the father or mother are associated with one more year of schooling for the child, and that a parent with a university degree is associated with a 34 percent higher likelihood that his or her children also will obtain such a degree. Another result, in columns 3 and 6 , is that the coefficient for either parent's education falls quite substantially when their partner's education is brought into the equation. Assortative mating on education lies behind this pattern.

The estimated intergenerational elasticities with respect to father's earnings and income are virtually identical and equal to 0.24. They are similar to those obtained by Björklund and Jäntti [1997] and Björklund and Chadwick [2003] for Sweden. 
In the second panel we report the results for specification (2) where our four outcomes for adoptees are run on the same variables for their adoptive and biological parents using the same format as before. The first three columns report the estimates for years of schooling. In column (1) we begin with the father-child link and find that the estimated effects of both the biological and adoptive father's years of schooling are statistically significant, positive and equally important. The estimate of 0.11 implies that one additional year of the biological or adoptive father's schooling raises the child's schooling by just over one-tenth of a year. In column (2) we consider the mother-child link. We observe positive and significant associations for both biological and adoptive mothers. Strikingly, however, the slope for biological mother's schooling of 0.13 is almost twice as high as the one for adoptive mothers.

Of course, the estimated transmission effects represent both the direct effect of the given parent's schooling and the indirect effect that comes from the other parent's schooling; the indirect effect is due to assortative mating on schooling, or on something else that correlates with schooling. In our sample, the years-of-schooling correlation between parents who adopt equals 0.49. Between adoptees' biological parents, however, this correlation is only 0.19. In column (3) we take the intergenerational effect of the partner into account by including both mothers' and fathers' schooling. For biological parents, the partial influences of both parents' years of schooling fall somewhat but remain statistically significant, positive and equally important. For adoptive parents, the partial schooling effects also fall, most notably for mothers. We find that the maternal schooling effect is no longer significant and close to zero while paternal schooling remains positive and significant. These results are in line with recent studies on intergenerational transmission of schooling that control for inherited ability 
and assortative mating and produce positive schooling effects for fathers but no effects for mothers; Behrman and Rosenzweig [2002], Plug [2004].

In columns 4-6 of Table II we switch the dependent and independent variable to a dummy for university degree. With this variable most of our findings are similar to those previously reported. The coefficients imply (a) that children with adoptive mothers and fathers with a university degree experience a significant higher chance of graduating from university themselves; (b) that for the intergenerational transmission of schooling, pre-birth factors also matter for university education; and (c) that the relative contribution of biological and adoptive parents are very similar to the ones obtained for years of schooling education, indicating that pre- and post-birth factors are equally important for father's schooling and that pre-birth circumstances are more important for mother's schooling. There is one notable difference. We find that the estimated university effect for adoptive mothers is positive and statistically significant with her partner's schooling included. Thus it seems that for university education both adoptive parents' education contribute to the education of the next generation.

We now turn to earnings and income. In column (7) we begin with the father-child link in earnings and find that higher earnings of the adoptive and biological father are associated with higher earnings of the child. The elasticities we estimate are 0.05 for the biological father's earnings and 0.10 for the adoptive father's earnings and only the latter is statistically significant.

The results for income, reported in column 8, are in line with what we observed for earnings. We find (a) positive and significant estimates for biological fathers; $(b)$ positive 
and significant slopes for adoptive fathers; and $(c)$ indications that adoptive fathers are more important than biological fathers in explaining the income link. ${ }^{19}$

In the bottom two rows of panel 2, we show the sum of the estimated coefficients for adoptive and biological parents of the adopted children. We find that, in most cases, the sum is only marginally different from the mobility estimate for a random sample of own-birth children (panel 1). Only for university education for mothers is the difference statistically significant.

We can learn four lessons from these adoption results. First, we find that biological parents matter. All our mobility specifications show positive and almost always significant slopes for biological fathers and mothers. The partial impacts we find for biological mothers' and fathers' education appear to be quite similar. This is exactly what we expected. As long as genes are automatically passed on from father to child and similarly from mother to child, the genetic effects should be identical. The small but positive differences between the effects of biological mothers and fathers further suggest that effects that run through the pre-natal environment are relatively small. Pre-natal effects are even smaller when we consider classification error as one of the alternative explanations. Suppose that the partial impacts of biological mothers and fathers are identical, but that fathers are more likely to be misclassified as biological fathers. We would then observe bigger effects for mothers. In adoption samples, where it might be more difficult to uncover the true identity of biological fathers, we would then expect classification errors to be higher for fathers than for mothers.

\footnotetext{
19 We here note that the impact of the income of the adoptive father is much larger than for earnings. The difference in sample size is not responsible. In an analysis not reported in the paper, we find that income effects remain the same when estimated on the smaller earnings sample. The explanation for the different estimates is that post-birth factors are more important for the intergenerational transmission of non-labor income (mainly capital income for this sample) than for earnings, and that the reverse is true for post-birth factors. Anyway, when we test for equality of earnings and income coefficients, a t-test of 1.54 does not reject equality ( $\mathrm{p}$-value $=0.123$ ).
} 
Second, we provide evidence that adoptive parents matter as well. In our schooling regressions, the positive and significant associations found for both parents do indicate that better educated parents provide a better environment for their children to do better in school.

Third, on the basis of a comparison of biological and adoptive parents, we find that most of the mother's influence on children takes place through pre-birth factors. For fathers we find pre- and post-birth factors to be equally important for education, whereas post-birth factors are more important for earnings and income.

Fourth, the total impact of the adoptive and biological parent's resources on the outcomes of adoptive children is remarkably similar to the impact of biological parent's outcomes for that of biological children. This indicates that adoption per se (the break from the biological mother, the time at the nursery) has almost no effect on the strength of the intergenerational schooling association among parents and children. ${ }^{20}$

\section{IV.B. RESULTS FOR MATCHED SAMPLES AND NON-LINEAR MODELS}

We first deal with the issue of comparing the results between adopted and own-birth children. As discussed in section II.A, we do this in two different ways. We consider ownbirth children whose parental characteristics are comparable with those of adoptees' birth parents'. We then consider own-birth children who are brought up in a childhood environment that is comparable with the post-childhood environment of adoptees.

20 Note that this does not hold for the estimated effects found for mothers with university degrees. 
In Table III we report results from matched samples using propensity scores. ${ }^{21}$ When we match the characteristics of the own-birth children's parents against the characteristics of the adoptees' biological parents, we find that all estimates are smaller than those observed for all own birth children. In most cases the reduction is statistically significant. When we make the samples more comparable by matching the characteristics of own-birth children's parents against the characteristics of adoptees' rearing parents, we get slopes that are very similar and in most cases statistically identical to those obtained for all own-birth children. If we compare the estimates using matched samples of own-birth children with the sum of the estimates for adoptees in Table II, we also see that they are quite similar.

Thus we conclude that our results using matched samples suggest that intergenerational associations of schooling, earnings and income for own-birth children are often stronger when we match on the adoptive parent's characteristics than when it is done on the biological parent's characteristics. If these findings also imply that intergenerational associations are much stronger in families that are better educated and generate more income, we might question whether the linear specifications we estimate in equations (1) and (2) are in fact linear. Our results indicate they are not.

We test for non-linear intergenerational transmissions by including the square of parental schooling and the square of father's earnings and income. In the first panel of table IV, where we report the new mobility estimates obtained from our representative sample of own-birth

21 The matching is done by regressing an indicator of adoption status ( 1 if adopted, 0 if non-adopted) on the following variables: 4 birth year dummies for the child, child's gender, 5 educational level dummies of the father and mother in 1970, father's and mother's income in 1970, dummies for father and mother having positive income in 1970, father's and mother's earnings in 1970, dummies for father and mother having positive earnings in 1970, about 50 birth year dummies for the father and mother, mother's marriage status measured in 5 categories in 1970, 57 two-digit occupation dummies for both parent's occupation in 1970, and 25 region dummies of the mother in 1965. When we match on adoptees' family environment (panel 3) we use the characteristics of the adoptive mother and father and when we match on adoptees' biological background (panel 4) we use the characteristics of the biological mother and father. All of the estimates were obtained using Leuven and Sianesi's [2003] psmatch2 program for Stata. 
children, we find that the estimates attached to the quadratic terms are always positive and statistically significant. This clearly suggests that the intergenerational associations are stronger in families with higher education and income. Our results correspond to the nonlinear intergenerational effects found in earlier mobility studies; Behrman and Taubman [1990], Solon [1992], Björklund and Chadwick [2003].

The question why intergenerational transmissions are so much stronger at the top than at the bottom of the schooling, earnings and income distribution is an important one. Some authors have argued that interactions between nature and nurture are very important (Dickens and Flynn 2001; Ridley 2003). And indeed, if smart children would benefit relatively more from having smart parents, the intergenerational transmissions would be greatest among high educated and high income families. Finding credible evidence, however, is difficult. Our adoption data offers a great opportunity to test whether this is the mechanism at work.

To estimate that part of the transmission that comes from the interaction between the postbirth environment (adoptive parents) and genetic factors (biological parents) we include the interacted effect between the education of the adoptive and biological parents and the earnings and income of the adoptive and biological fathers. This is done in the second panel of Table IV. We find evidence of a positive interaction for mother's education and father's earnings and income, but not for father's education. To test whether these interacted effects are not picking up other non-linear effects that possibly exist between parents and their children, we also include the square of parental education, earnings and income. Our results indicate that this is not the case. The interacted estimates are not sensitive to the inclusion of higher order terms. 


\section{SENSITIVITY CHECKS USING ALTERNATIVE SAMPLES AND SPECIFICATIONS}

While our estimates suggest that for adoptees both their adoptive and birth parents matter, we should treat these estimates with care. Several problems involved in using adoption data could lead to misinterpretations. In this section we concentrate on four of these, being (a) not all adoptees are adopted as babies; $(b)$ many adoptees have unknown birth fathers; $(c)$ nonrandom placement of adoptees to their adoptive families; and $(d)$ adoptees and adoptive parents are different from other children and their parents. To examine the impact of each of these four problems, we will focus our attention to specifications that use years of schooling and earnings for reasons of brevity. ${ }^{22}$

A possible weakness of our adoption approach is that some children are adopted at a later age. If a significant number of adoptees are not adopted as babies, we end up overestimating pre-birth effects and underestimating post-birth effects. So far we have ignored adoption age and implicitly assumed that adoption took place at birth. With respect to the obtained effects for the adoptees' birth parents this seems a reasonable assumption. In Sweden possible postbirth effects that come from the adoptees' birth parents do not exist for most adoptees since most children that are registered for adoption are placed in special nursery houses the moment they are born. With respect to the obtained effects estimated for the adoptive parents, we are not so sure whether the adoption-at-birth assumption is likely to hold. The problem is that within our set-up it is difficult to measure adoption age. We can infer the age at adoption only crudely from the time we observe whether children are adopted or not in the

\footnotetext{
22 We have also compared the results with those obtained for university education and income. We found no systematic differences. Sensitivity results for university education and income are available upon request.
} 
censuses of 1965 or 1970 . If we look at those adoptees born exactly one year prior to the census date in 1965 -meaning those who are born between October and December 1964- we find that about 80 percent of all adoptees (94 out of 117) are formally adopted within a year. If this is typical for adoptees during this time, it implies that about 80 percent of all our adoptees are adopted within a year of their birth date. We therefore do not worry too much about this issue. We still perform some sensitivity analysis by restricting our adoption sample to all children between 0 and 2 who are adopted at the time we observe them in the census. ${ }^{23}$ With this subsample, we can estimate the effects that come from the adoptive parents more accurately looking at adoptees who are more likely to be adopted as babies and receive the full parental treatment. Results are reported in row 2 of Table 5. Other than the reduction in sample size, we find that the estimates attached to the parental schooling and earnings variables for adoptees adopted as babies are very similar to the ones we observe for the full sample. These results give no compelling reason to believe that timing of adoption seriously affects our estimates.

A second problem could arise because we have restricted our sample of adoptees to those for which we have information on both biological parents. But for almost half of the original sample the father is unknown. It is possible that children with unknown birth fathers are different from other children in ways related to their parental outcomes. To test whether absent information on the father affects the estimates, we extend the current sample of adoptees with adoptees for which we have only information on birth mothers. In row 3 of Table V we report schooling estimates for birth and adoptive mothers that are almost

\footnotetext{
23 These children are born between November 1963 and November 1965, and live with their adoptive parents at the time we observe them in the census in (November) 1965.
} 
identical to the ones observed for the restricted sample (but with higher precision). We therefore rule out this source of bias.

Our third problem, that children are not randomly placed in their new families, is a muchdiscussed one in adoption studies. With detailed information on the adoptees' biological background, however, we can test the sensitivity of our adoption results to non-random assignment. We first investigate whether there is evidence of non-random assignment of adoptees (selective placement) in Sweden and estimate the relationship between between the education and earnings characteristics of the adoptive and biological parents of adoptees. Random assignment would give us zero correlations. We, on the other hand, find correlations that range from 0.091 for fathers' earnings to $0.144(0.140)$ for fathers' (mothers') years of schooling. These numbers are quite high and suggest that non-random assignment among adoptees and their adoptive parents is substantial. ${ }^{24}$ We therefore propose the following tests. We check how the estimates attached to the adoptive parent's schooling and earnings change when we (a) exclude the biological parent's controls for schooling and earnings; and (b) include as many background characteristics of the biological parents available and measured around the time of adoption. ${ }^{25}$ In rows 4 and 5 of panel 2 in Table $\mathrm{V}$, we show that the coefficients that correspond to the adoptive parent's outcomes rise (fall) when we exclude (include) the biological parent's schooling or earnings, but not by much. The only exception appears to be the estimate for the adoptive father's earnings in row 5, which is much smaller than the one we observe in our baseline. Yet the difference is not significantly different. In

\footnotetext{
24 These correlations are not driven by age and region effects. When we regress out age and region effects, the correlations remain virtually identical. Also, note that the magnitude of the correlations is very similar to the correlations in IQ between the biological and adoptive mother/father found in one of the most well known samples of adoptees used for research purposes, the Texas Adoption Study [Brody 1992].

${ }_{25}$ Biological parent's age, marital status, education, earnings, income, occupation and regional controls measured at 1965 or 1970 .
} 
addition to these results, it is also useful to see what happens to the coefficients of the adoptees' birth parents when we exclude and include information of the adoptive parents. The estimates attached to the adoptees' birth parents in columns 6 and 7 appear to be even less sensitive to the inclusion (exclusion) of the adoptive parents' characteristics. The coefficients change, but they change only in the margin. In the end, we do not believe that selective placement is affecting our results in a substantial way as results remain qualitatively very similar whether we exclude or include variables.

Finally, we address the problem that adoptees and adoptive parents are different from other children and their parents. In our analysis with more comparable samples we rely on matching (section IV.B.). The disadvantage of matching is that since it is unlikely that we observe all the relevant characteristics of the adoptees' birth and adoptive parents we may not eliminate all the differences between adoptees and own-birth children. We therefore present results for particular subsamples. .

We begin with limiting our adoptive sample to those families who also have own-birth children. The adopted and own-birth children in these families share the same childhood environment, but not the pre-birth experience. If estimates for adoptees are to be informative about intergenerational associations between own-birth children and their parents, we expect estimates for adopted children with own-birth siblings to be similar to the estimates for all adoptive children. In addition, we expect that the estimates for own-birth children with adopted siblings to be similar to estimates for the representative sample of own-birth children. Rows 1 and 8 indicate that most of the estimates for adoptive children in these families are quite similar to estimates for the sample of all adopted children. In rows 9 and 10 we see that the estimates for own-birth children in adoptive families are somewhat bigger 
than the estimates for the representative sample of own-birth children. If we assume that parents do not differentiate between their own-birth and adopted children, these results are consistent with our finding that intergenerational correlations are stronger in families who are at the top of the education and income distribution. ${ }^{26}$ We then limit our birth sample to those children born in families in which at least one child is given up for adoption. We know that these own-birth children share similar genes and pre-childhood experiences with adoptees, and that they therefore start their lives under very similar conditions as adoptees do. When we estimate previous intergenerational relationships using these particular birth children, we find schooling and earnings estimates that are smaller than those observed for all own birth children. Again, if we assume that parents adopt their child away for reasons that are unrelated to the child's characteristics, these results are in line with what we find earlier: intergenerational estimates are lower in families who are at the bottom of the education and income distribution. ${ }^{27}$ Overall, we find that subsampling and matching generate similar patterns.

\section{CONCLUSIONS}

In this paper we investigate the origins of intergenerational education and income associations using data on Sweden-born adoptees and their biological and adoptive parents. Our empirical strategy is to decompose the intergenerational association into prebirth and post-birth components, or combinations thereof. We use biological parent's

\footnotetext{
26 If we do not want to shy away from possible treatment differentials, these findings also indicate that parents may favor their own offspring over their adopted children. Case, Lin and McLanahan (2000) propose selfish genes as one of the responsible mechanisms.

27 But if parents (mostly mothers) could choose and rather put their problematic child up for adoption, it is possible that we find lower correlations because these children are less sensitive to parental treatments.
} 
characteristics as an indicator of genetic background and pre-natal environment, and adoptive parent's characteristics as indicator of the child's post-birth environment. Our conclusions follow from regressions where we include the biological and adoptive parent's characteristics simultaneously into intergenerational mobility equations.

We find that both pre- and post-birth factors are important for the child's educational and economic outcomes. That is, for none of the outcomes studied these factors can be said to be negligible. The relative contributions fluctuate a bit. For mother's education, for example, we find that pre-birth factors are more important than post-birth environment, whereas for father's long-run earnings and income, the post-birth environment is more important than pre-birth factors. We also find evidence of slightly larger intergenerational transmission coefficients for biological mothers than for biological fathers. Because the impact of the biological mother reflects both genetic and pre-natal environmental factors, whereas the impact of the biological father reflects only genetic factors, we believe that pre-natal environmental factors are small in magnitude. This in turn allows us to discuss our estimated pre- and post-birth effects using the classical nature and nurture labels. For example, we can interpret our estimated interactions effects between biological and adoptive parents' status as nature-nurture interactions. Interestingly, such interactions are positive and significantly different from zero, for mother's education and father's income. These interactions further corroborate our conclusion that both pre- and post-birth factors are important, but also suggest that the importance of nurture varies across the nature distribution.

What are the implications of these findings? First, we provide evidence that both adoptive and biological parents matter, which suggests that both nature and nurture 
components are important. This implies that any comprehensive explanatory theory of intergenerational mobility must incorporate both factors like genetic heredity and factors in the rearing family. Any theory that only focuses on one of these will be incomplete. These results also help us to understand why specific policies have an impact on intergenerational mobility. For instance, welfare policies can increase mobility by improving the environment in which children are raised. Further, anti-discrimination policies can increase mobility by reducing the impact of physical characteristics that are genetically determined. Second, our findings with respect to the positive nature and nurture interactions also raise some interesting issues. Both nature and nurture remain important, but if the two operate together, it becomes very difficult to separate one from another. To improve equality of opportunity, many policies are designed to improve the conditions for particularly children raised in low educated and poor families. After all, in the presence of interactions these children suffer most from being less able, being raised under poorer conditions, and the interactions between the two. At the same time, these results also suggest why policies like these have not always been that effective in the past.

SWEDISH INSTITUTE FOR SOCIAL RESEARCH (SOFI), STOCKHOLM UNIVERSITY SWEDISH INSTITUTE FOR SOCIAL RESEARCH (SOFI), STOCKHOLM UNIVERSITY DEPARTMENT OF ECONOMICS, TINBERGEN INSTITUTE, UNIVERSITY OF AMSTERDAM 


\section{References:}

Behrman, Jere and Paul Taubman, “The Intergenerational Correlation Between Children's Adult Earnings and their Parents' Income: Results from the Michigan Panel Survey of Income Dynamics”, Review of Income and Wealth, 36 (1990), 115-127.

Behrman, Jere and Mark Rosenzweig, “Does Increasing Women’s Schooling Raise the Schooling of the Next Generation?”, American Economic Review, 92 (2002), 323-334.

Björklund Anders and Laura Chadwick, "Intergenerational Income Mobility in Permanent and Separated Families”, Economics Letters, 80 (2003), 239-246.

Björklund Anders and Markus Jäntti, "Intergenerational Income Mobility in Sweden Compared to the United States”, American Economic Review, 87 (1997), 1009-1018.

Björklund Anders, Markus Jäntti and Gary Solon, "Influences of Nature and Nurture on Earnings Variation: A Report on a Study of Sibling Types in Sweden”, in Sam Bowles, Herb Gintis and Melissa Osborne, eds., Unequal chances: Family Background and Economic Success (New York: Russel Sage Foundation, 2005).

Björklund, Anders, Mikael Lindahl and Erik Plug, "Intergenerational Effects in Sweden: What can we Learn from Adoption Data?”, IZA DP no. 1194, 2004.

Bohman, Michael, Adopted Children and their Families, (Stockholm: Proprius, 1970).

Brody, Nathan, Intelligence, $2^{\text {nd }}$ edition. (San Diego CA: Academic Press, 1992).

Böhlmark Anders and Matthew Lindquist, "Life-Cycle Variations in the Association between Current and Lifetime Income: Country, Gender and Cohort Differences”, Swedish Institute for Social Research, WP 4/2005, 2005.

Case, Anne, I-Fen Lin and Sara McLanahan, "How Hungry is the Selfish Gene?” Economic Journal 110 (2000), 781-804.

Cunha, Flavio, James J. Heckman, Lance Lochner and Dimitry V. Masterov, “Interpreting the Evidence on Life Cycle Skill Formation”, NBER WP no. 11331, 2005.

Das, Mitali and Tanja Sjogren, "The Inter-generational Link in Income Mobility: Evidence from Adoptions”, Economics Letters 75 (2002), 55-60.

Dickens, W. T. and J. R. Flynn, "Heritability Estimates versus Large Environmental Effects: The IQ Paradox Resolved”, Psychological Review 108, (2001), 346-369.

Haider, Steven J. and Gary Solon, "Life-Cycle Variation in the Association between Current and Lifetime Earnings”, (2005), manuscript. 
Leuven, Edwin and Sianesi, Barbara, "psmatch2: Stata module to perform full Mahalanobis and propensity score matching, common support graphing, and covariate imbalance testing”, http://ideas.repec.org/c/boc/bocode/s432001.html., version X.x.x., 2003.

Plomin, Robert, John C. DeFries and David W. Fulker, Nature and Nurture During Infancy and Early Childhood, (Cambridge University Press, 1988).

Plug, Erik, "Estimating the Effect of Mother's Schooling on Children's Schooling Using a Sample of Adoptees”, American Economic Review 94 (2004), 358-368.

Plug, Erik and Wim Vijverberg, "Does Family Income Matter For Schooling Outcomes? Using Adoption As a Natural Experiment”, Economic Journal 115 (2005), 880-907.

Plug Erik and Wim Vijverberg, "Schooling, Family Background, and Adoption: Is It Nature or Is It Nurture?”, Journal of Political Economy 111 (2003), 611-641.

Ridley, Matt, Nature via Nurture, (New York: Harper Collins, 2003)

Sacerdote Bruce, “The Nature and Nurture of Economic Outcomes”, NBER WP no. 7949, 2003.

"The Nature and Nurture of Economic Outcomes", American Economic Review Papers and Proceedings 92 (2002), 344-348.

“What Happens When We Randomly Assigning Children to Families?”, NBER WP no. 10894, 2004

Scarr, Sandra and Richard Weinberg, "The Influence of Family Background on Intellectual Attainment,” American Sociological Review 58 (1978), 674-692.

Solon, Gary, “Intergenerational Income Mobility in the United States”, American Economic Review, 82 (1992), 393-408.

, "Intergenerational Mobility in the Labor Market", in Orley Ashenfelter and David Card, eds., Handbook of Labor Economics, vol. 3, (Amsterdam: Elsevier, 1999).

Turkheimer, Eric, Andreana Haley, Mary Waldron, Brian D’Onofrio and Irving I. Gottesman, "Socioeconomic Status Modifies Heritability of IQ in Young Children”, Psychological Science, 14 (2003), 623-628. 
TABLE I

MEANS AND STANDARD DEVIATIONS OF VARIABLES FOR CHILDREN AND PARENTS

\begin{tabular}{|c|c|c|c|c|}
\hline \multirow[b]{3}{*}{ Years of schooling } & \multicolumn{2}{|c|}{ Own-birth children } & \multicolumn{2}{|c|}{ Adopted children } \\
\hline & \multicolumn{4}{|c|}{ Children } \\
\hline & 12.07 & 2.07 & 11.67 & 1.89 \\
\hline University education & 0.32 & 0.47 & 0.24 & 0.43 \\
\hline Log earnings in 1999 & 7.54 & 0.67 & 7.43 & 0.72 \\
\hline Log income in 1999 & 7.62 & 0.56 & 7.53 & 0.58 \\
\hline Male & 0.51 & 0.50 & 0.52 & 0.50 \\
\hline \multirow[t]{2}{*}{ Age in 1999} & 35.29 & 1.42 & 35.49 & 1.42 \\
\hline & \multicolumn{4}{|c|}{ Birth parents } \\
\hline Years of schooling, father & 9.63 & 3.12 & 8.90 & 2.51 \\
\hline Years of schooling, mother & 9.65 & 2.83 & 9.12 & 2.43 \\
\hline University education, father & 0.16 & 0.36 & 0.07 & 0.26 \\
\hline University education, mother & 0.16 & 0.37 & 0.08 & 0.28 \\
\hline Average log earnings $1970-90$, father & 7.67 & 0.44 & 7.38 & 0.51 \\
\hline Average log income 1970-90, father & 7.69 & 0.43 & 7.40 & 0.46 \\
\hline Age when child is born, father & 30.37 & 6.58 & 26.88 & 6.96 \\
\hline Age when child is born, mother & 27.09 & 5.73 & 23.35 & 5.80 \\
\hline Teenage mother & 0.09 & 0.29 & 0.32 & 0.47 \\
\hline \multirow[t]{2}{*}{ Teenage father } & 0.02 & 0.14 & 0.12 & 0.33 \\
\hline & \multicolumn{4}{|c|}{ Adoptive parents } \\
\hline Years of schooling, father & & & 10.20 & 3.31 \\
\hline Years of schooling, mother & & & 9.67 & 2.99 \\
\hline University education, father & & & 0.20 & 0.40 \\
\hline University education, mother & & & 0.18 & 0.39 \\
\hline Average log earnings $1970-90$, father & & & 7.77 & 0.47 \\
\hline Average log income 1970-90, father & & & 7.81 & 0.44 \\
\hline Age when child is born, father & & & 35.66 & 5.36 \\
\hline Age when child is born, mother & & & 32.96 & 4.93 \\
\hline Number of observations & \multicolumn{2}{|c|}{94,079} & & \\
\hline
\end{tabular}

Notes: Standard deviations are shown in italics; The exceptions to the stated number of observations are: for log earnings in 1999: 87,490 for own-birth children and 1,827 for adopted children, for log income in 1999: 92,168 for own-birth children and 1,998 for adopted children. For average log earnings 1970-1999: 93,627 for birth fathers of own-birth children, 2,078 for birth fathers of adopted children and 1,981 for adoptive fathers of adopted children. For average log income 1970-1999: 93,831 (101,027) for birth fathers of own-birth children, 2,107 for birth fathers of adopted children and 2,120 for adoptive fathers of adopted children. 
TABLE II

ESTIMATED TRANSMISSION COEFFICIENTS IN LINEAR MODELS

\begin{tabular}{|c|c|c|c|c|c|c|c|c|}
\hline \multirow[b]{3}{*}{ Own-birth children } & \multicolumn{3}{|c|}{ Years of Schooling } & \multicolumn{3}{|c|}{ University } & \multirow{2}{*}{$\begin{array}{l}\text { Earnings } \\
\text { (7) }\end{array}$} & \multirow{2}{*}{$\begin{array}{l}\text { Income } \\
\text { (8) }\end{array}$} \\
\hline & $(1)$ & $(2)$ & (3) & (4) & (5) & (6) & & \\
\hline & & & & & & & & \\
\hline$\overline{\text { Bio father }}$ & $\begin{array}{l}.240^{* *} \\
(.002)\end{array}$ & & $\begin{array}{l}.170^{* *} \\
(.002)\end{array}$ & $\begin{array}{l}.339 * * \\
(.004)\end{array}$ & & $\begin{array}{l}.237 * * \\
(.004)\end{array}$ & $\begin{array}{l}.235^{* *} \\
(.005)\end{array}$ & $\begin{array}{l}.241^{* *} \\
(.004)\end{array}$ \\
\hline Bio mother & & $\begin{array}{l}.243^{* *} \\
(.002)\end{array}$ & $\begin{array}{l}.158^{* *} \\
(.002)\end{array}$ & & $\begin{array}{l}.337 * * \\
(.004)\end{array}$ & $\begin{array}{l}.246^{* *} \\
(.004)\end{array}$ & & \\
\hline \multicolumn{9}{|l|}{ Adopted children } \\
\hline$\overline{\text { Bio father }}$ & $\begin{array}{l}.113^{* *} \\
(.016)\end{array}$ & & $\begin{array}{l}.094^{* *} \\
(.016)\end{array}$ & $\begin{array}{l}.184^{* *} \\
(.036)\end{array}$ & & $\begin{array}{l}.148 * * \\
(.036)\end{array}$ & $\begin{array}{l}.047 \\
(.034)\end{array}$ & $\begin{array}{l}.059^{*} \\
(.028)\end{array}$ \\
\hline Bio mother & & $\begin{array}{l}.132^{* *} \\
(.017)\end{array}$ & $\begin{array}{l}.101^{* *} \\
(.017)\end{array}$ & & $\begin{array}{l}.261^{* *} \\
(.034)\end{array}$ & $\begin{array}{l}.229 * * \\
(.034)\end{array}$ & & \\
\hline Adoptive father & $\begin{array}{l}.114^{* *} \\
(.013)\end{array}$ & & $\begin{array}{l}.094^{* *} \\
(.014)\end{array}$ & $\begin{array}{l}.165^{* *} \\
(.024)\end{array}$ & & $\begin{array}{l}.102 * * \\
(.026)\end{array}$ & $\begin{array}{l}.098 * * \\
(.038)\end{array}$ & $\begin{array}{l}.172 * * \\
(.031)\end{array}$ \\
\hline Adoptive mother & & $\begin{array}{l}.074^{* *} \\
(.014)\end{array}$ & $\begin{array}{l}.021 \\
(.015)\end{array}$ & & $\begin{array}{l}.145^{* *} \\
(.024)\end{array}$ & $\begin{array}{l}.097 * * \\
(.026)\end{array}$ & & \\
\hline $\begin{array}{l}\text { Sum of estimates for } \\
\text { bio and adoptive } \\
\text { fathers }\end{array}$ & $\begin{array}{l}.227^{* *} \\
(.019)\end{array}$ & & $\begin{array}{l}.188^{* *} \\
(.029)\end{array}$ & $\begin{array}{l}.349 * * \\
(.040)\end{array}$ & & $\begin{array}{l}.249 * * \\
(.059)\end{array}$ & $\begin{array}{l}.145^{* *} \\
(.049)\end{array}$ & $\begin{array}{l}.231^{* *} \\
(.040)\end{array}$ \\
\hline $\begin{array}{l}\text { Sum of estimates for } \\
\text { bio and adoptive } \\
\text { mothers }\end{array}$ & & $\begin{array}{l}.207 * * \\
(.021)\end{array}$ & $\begin{array}{l}.122^{* *} \\
(.016)\end{array}$ & & $\begin{array}{l}.406^{* *} \\
(.039)\end{array}$ & $\begin{array}{l}.326 * * \\
(.029)\end{array}$ & & \\
\hline
\end{tabular}

Notes: Standard errors are shown in parentheses; * indicates significance at 5\% level, and ** at 1\% level; All specifications include controls for the child's gender, 4 birth cohort dummies for the child, 8 birth cohort dummies for biological/adoptive father/mother and 25 region dummies of where the biological/adoptive family lived in 1965 . The numbers of observations in the second panel for own birth and adopted children are: 94,079/2,125 in columns 1-6, 87,079/1,780 in columns 7 and 91,932/1,976 in column 8 . 
TABLE III

ESTIMATES FROM MATCHED SAMPLES USING PROPENSITY SCORES

Years of Schooling

(1)

(2)

(3)

(4)

(5)

(6)

Own-birth children

Representative sample

Bio father

$\begin{array}{lll}.240 * * & & .170 * * \\ (.002) & & (.002) \\ & .243^{* *} & .158^{* *} \\ & (.002) & (.002)\end{array}$

\section{$.338^{* *}$ \\ $(.004)$}

Bio mother d:

Bio father

$.199^{* *}$

Bio mother

$\begin{array}{lll}.199 * * & & .155^{* *} \\ (.008) & & (.009) \\ & .196 * * & .148^{* *} \\ & (.009) & (.009)\end{array}$

Matched on adoptees' rearing

background:

Bio father

Bio mother
$.325 * *$

(.006)

$.248^{* *}$
$(.003)$

$.248^{* *}$
$(.003)$

$\begin{array}{ll} & .176 * * \\ & (.004) \\ .254 * * & .152 * * \\ (.004) & (.004)\end{array}$

Earnings

Income

Earnings

Notes: Standard errors are shown in parentheses; * indicates significance at 5\% level, and ** at 1\% level; All specifications include controls for: child's gender, 4 birth cohort dummies for the child, 8 birth cohort dummies for biological/adoptive father's/mother's and 25 region dummies of where the biological/adoptive family lived in 1965 .

The numbers of observations in the first/second/third panel are 94,079/93,655/84,358 for years of schooling and university, 87,079/86,703/78,229 for earnings

and 91,932/91,532/82,536 for income. 
TABLE IV

ESTIMATED TRANSMISSION COEFFICIENTS IN NON-LINEAR MODELS WITH INTERACTIONS

\begin{tabular}{|c|c|c|c|c|c|c|c|c|c|c|}
\hline & \multicolumn{4}{|c|}{ Years of schooling } & \multicolumn{2}{|c|}{ University } & \multirow{2}{*}{\multicolumn{2}{|c|}{$\begin{array}{l}\text { Earnings } \\
\text { Fathers }\end{array}$}} & \multirow{2}{*}{\multicolumn{2}{|c|}{$\begin{array}{l}\text { Income } \\
\text { Fathers }\end{array}$}} \\
\hline & \multicolumn{2}{|c|}{$\underline{\text { Fathers }}$} & \multicolumn{2}{|c|}{$\underline{\text { Mothers }}$} & \multirow{2}{*}{$\begin{array}{l}\text { Fathers } \\
\text { (5) }\end{array}$} & \multirow{2}{*}{$\frac{\text { Mothers }}{(6)}$} & & & & \\
\hline & (1) & (2) & (3) & (4) & & & (7) & (8) & (9) & (10) \\
\hline \multicolumn{11}{|l|}{ Own-birth children } \\
\hline$\overline{\text { Bio parent }}$ & & $\begin{array}{l}-.009 \\
(.015)\end{array}$ & & $\begin{array}{l}-.058^{* *} \\
(.017)\end{array}$ & & & & $\begin{array}{l}-.807^{* *} \\
(.075)\end{array}$ & & $\begin{array}{l}-.938 * * \\
(.064)\end{array}$ \\
\hline Bio parent squared & & $\begin{array}{l}.011^{* *} \\
(.001)\end{array}$ & & $\begin{array}{l}.014 * * \\
(.001)\end{array}$ & & & & $\begin{array}{l}.069 * * \\
(.005)\end{array}$ & & $\begin{array}{l}.077^{* *} \\
(.004)\end{array}$ \\
\hline \multicolumn{11}{|l|}{ Adopted children } \\
\hline$\overline{\text { Bio parent }}$ & $\begin{array}{l}.050 \\
(.051)\end{array}$ & $\begin{array}{l}-.222 \\
(.127)\end{array}$ & $\begin{array}{l}-.055 \\
(.055)\end{array}$ & $\begin{array}{l}-.472 * * \\
(.139)\end{array}$ & $\begin{array}{l}.199 * * \\
(.045)\end{array}$ & $\begin{array}{l}.166^{* *} \\
(.041)\end{array}$ & $\begin{array}{l}-.187 \\
(.108)\end{array}$ & $\begin{array}{l}-.403 \\
(.502)\end{array}$ & $\begin{array}{l}-1.164^{*} \\
(.525)\end{array}$ & $\begin{array}{l}-1.342^{*} \\
(.670)\end{array}$ \\
\hline Bio parent squared & & $\begin{array}{l}.015^{*} \\
(.006)\end{array}$ & & $\begin{array}{l}.023^{* *} \\
(.006)\end{array}$ & & & & $\begin{array}{l}.017 \\
(.037)\end{array}$ & & $\begin{array}{l}.015 \\
(.034)\end{array}$ \\
\hline Adoptive parent & $\begin{array}{l}.061 \\
(.043)\end{array}$ & $\begin{array}{l}-.003 \\
(.090)\end{array}$ & $\begin{array}{l}-.097 \\
(.050)\end{array}$ & $\begin{array}{l}-.310^{* *} \\
(.121)\end{array}$ & $\begin{array}{l}.170 * * \\
(.025)\end{array}$ & $\begin{array}{l}.108 * * \\
(.026)\end{array}$ & $\begin{array}{l}-.293^{*} \\
(.125)\end{array}$ & $\begin{array}{l}-.076 \\
(.648)\end{array}$ & $\begin{array}{l}-.995^{*} \\
(.501)\end{array}$ & $\begin{array}{l}-.998 \\
(.710)\end{array}$ \\
\hline $\begin{array}{l}\text { Adoptive parent } \\
\text { squared }\end{array}$ & & $\begin{array}{l}.004 \\
(.004)\end{array}$ & & $\begin{array}{l}.012^{*} \\
(.005)\end{array}$ & & & & $\begin{array}{l}-.003 \\
(.043)\end{array}$ & & $\begin{array}{l}.003 \\
(.035)\end{array}$ \\
\hline $\begin{array}{l}\text { Bio parent*Adoptive } \\
\text { parent }\end{array}$ & $\begin{array}{l}.006 \\
(.004)\end{array}$ & $\begin{array}{l}.003 \\
(.005)\end{array}$ & $\begin{array}{l}.018^{* *} \\
(.005)\end{array}$ & $\begin{array}{l}.013^{*} \\
(.005)\end{array}$ & $\begin{array}{l}-.041 \\
(.074)\end{array}$ & $\begin{array}{l}.286 * * \\
(.071)\end{array}$ & $\begin{array}{l}.043^{* *} \\
(.015)\end{array}$ & $\begin{array}{l}.034^{* *} \\
(.010)\end{array}$ & $\begin{array}{l}.156^{*} \\
(.067)\end{array}$ & $\begin{array}{l}.151^{*} \\
(.068)\end{array}$ \\
\hline
\end{tabular}

Notes: Standard errors are shown in parentheses; * indicates significance at 5\% level, and ** at 1\% level; All specifications include controls for the child's gender, 4 birth cohort dummies for the child, 8 birth cohort dummies for biological/adoptive father/mother and 25 region dummies of where the biological/adoptive family lived in 1965 . The numbers of observations in the second panel for own birth and adopted children are: 94,079/2,125 in columns 1-6, 87,079/1,780 in columns 7 and 91,932/1,976 in column 8 . 
TABLE V

SENSITIVITY ANALYSES: ALTERNATIVE SAMPLES AND SPECIFICATIONS

Years of schooling

Earnings

Adopted children

(1) Baseline results:

$(\mathrm{N}=2125,1780)$

\section{Other samples:}

Age of adoption

(2) adopted between age 0

and $2(\mathrm{~N}=638,573)$

Missing birth fathers

(3) including those without info on birth fathers

$(\mathrm{N}=4123)$

Non random assignment

(4) exclude info on birth

parents $(\mathrm{N}=2125,1780)$

(5) include info on birth

parents $(\mathrm{N}=2125,1780)$

(6) exclude info on adoptive parents $(\mathrm{N}=2125,1780)$

(7) include info on adoptive parents $(\mathrm{N}=2125,1780)$

\begin{tabular}{|c|c|c|c|c|c|}
\hline \multicolumn{2}{|c|}{$\underline{\text { Fathers }}$} & \multicolumn{2}{|c|}{$\underline{\text { Mothers }}$} & \multicolumn{2}{|c|}{$\underline{\text { Fathers }}$} \\
\hline Adopt. & $\underline{\mathrm{Bio}}$ & Adopt & $\underline{B i o}$ & $\underline{\text { Adopt }}$ & $\underline{B i o}$ \\
\hline $\begin{array}{l}.114^{* *} \\
(.013)\end{array}$ & $\begin{array}{l}.113^{* *} \\
(.016)\end{array}$ & $\begin{array}{l}.075^{* *} \\
(.014)\end{array}$ & $\begin{array}{l}.132 * * \\
(.017)\end{array}$ & $\begin{array}{l}.098 * * \\
(.038)\end{array}$ & $\begin{array}{l}.047 \\
(.034)\end{array}$ \\
\hline $\begin{array}{l}.120 * * \\
(.024)\end{array}$ & $\begin{array}{l}.109 * * \\
(.030)\end{array}$ & $\begin{array}{l}.062 * \\
(.026)\end{array}$ & $\begin{array}{l}.124^{* *} \\
(.033)\end{array}$ & $\begin{array}{l}.124 \\
(.074)\end{array}$ & $\begin{array}{l}.079 \\
(.067)\end{array}$ \\
\hline & & $\begin{array}{l}.083 * * \\
(.010)\end{array}$ & $\begin{array}{l}.128 * * \\
(.012)\end{array}$ & & \\
\hline $\begin{array}{l}.126 * * \\
(.013) \\
.097 * * \\
(.013)\end{array}$ & & $\begin{array}{l}.093^{* *} \\
(.014) \\
.055^{*} \\
(.015)\end{array}$ & & $\begin{array}{l}.095^{*} \\
(.037) \\
.027 \\
(.039)\end{array}$ & \\
\hline & $\begin{array}{l}.132 * * \\
(.016) \\
.105 * * \\
(.017)\end{array}$ & & $\begin{array}{l}.150^{* *} \\
(.017) \\
.117^{* *} \\
(.018)\end{array}$ & & $\begin{array}{l}.045 \\
(.033) \\
.038 \\
(.034)\end{array}$ \\
\hline $\begin{array}{l}.129 * * \\
(.024)\end{array}$ & $\begin{array}{l}.059 \\
(.034)\end{array}$ & $\begin{array}{l}.052 \\
(.030)\end{array}$ & $\begin{array}{l}.114^{* *} \\
(.035)\end{array}$ & $\begin{array}{l}.035 \\
(.077)\end{array}$ & $\begin{array}{l}.123 \\
(.064)\end{array}$ \\
\hline & $\begin{array}{l}.240 * * \\
(.002)\end{array}$ & & $\begin{array}{l}.243^{* *} \\
(.002)\end{array}$ & & $\begin{array}{l}.235^{* *} \\
(.005)\end{array}$ \\
\hline & $\begin{array}{l}.285^{* *} \\
(.031) \\
.180^{* *} \\
(.056)\end{array}$ & & $\begin{array}{l}.251^{* *} \\
(.035) \\
.106 \\
(.067)\end{array}$ & & $\begin{array}{l}.280 * * \\
(.080) \\
.216 \\
(.113)\end{array}$ \\
\hline
\end{tabular}

Sub samples

(8) raised with own-birth

siblings $(\mathrm{N}=526,435)$

Own-birth children

(9) Baseline results:

( $\mathrm{N}=940792,87079)$

Other samples:

(10) raised with adopted

siblings $(\mathrm{N}=412$, 381)

(11) with bio siblings adopted out $(\mathrm{N}=193,160)$

Notes: Standard errors are shown in parentheses; * indicates significance at 5\% level, and ** at $1 \%$ level; All specifications include controls for the child's gender, 4 birth cohort dummies for the child, 8 birth cohort dummies for biological/adoptive father/mother and 25 region dummies of where the biological/adoptive family lived in 1965; Also sample sizes are shown in parentheses. For instance, in row $2(\mathrm{~N}=638,573)$ means that number of observations is 638 in columns 1-4 (for years of schooling) and 573 in columns 5-6 (for earnings). 


\section{APPENDIX TABLE (NOT INTENDED FOR PUBLICATION) SENSITIVITY ANALYSES: ALTERNATIVE SAMPLES AND SPECIFICATIONS}

Adopted children

(1) Baseline results: $(\mathrm{N}=2125,1976)$

\section{University}

Income

\section{Other samples:}

Age of adoption

(2) adopted between age 0

and $2(\mathrm{~N}=638,602)$

Missing birth fathers

(3) including those without info on birth fathers

$(\mathrm{N}=4123)$

Non random assignment

(4) exclude info on birth

parents $(\mathrm{N}=2125,1976)$

(5) include info on birth

parents $(\mathrm{N}=2125,1976)$

(6) exclude info on adoptive parents $(\mathrm{N}=2125,1976)$

(7) include info on adoptive

\begin{tabular}{|c|c|c|c|c|c|}
\hline \multicolumn{4}{|c|}{$\underline{\text { University }}$} & \multirow{2}{*}{\multicolumn{2}{|c|}{$\begin{array}{l}\text { Income } \\
\text { Fathers }\end{array}$}} \\
\hline \multicolumn{2}{|c|}{$\underline{\text { Fathers }}$} & \multicolumn{2}{|c|}{ Mothers } & & \\
\hline Adopt. & $\underline{\mathrm{Bio}}$ & $\underline{\text { Adopt }}$ & $\underline{\mathrm{Bio}}$ & Adopt & $\underline{\mathrm{Bio}}$ \\
\hline $\begin{array}{l}.165^{* *} \\
(.024)\end{array}$ & $\begin{array}{l}.184^{* *} \\
(.036)\end{array}$ & $\begin{array}{l}.145^{* * *} \\
(.024)\end{array}$ & $\begin{array}{l}.261^{* *} \\
(.034)\end{array}$ & $\begin{array}{l}.172 * * \\
(.031)\end{array}$ & $\begin{array}{l}.059 * \\
(.028)\end{array}$ \\
\hline $\begin{array}{l}.224^{* *} \\
(.042)\end{array}$ & $\begin{array}{l}.314^{* *} \\
(.068)\end{array}$ & $\begin{array}{l}.100 * \\
(.045)\end{array}$ & $\begin{array}{l}.228 * * \\
(.062)\end{array}$ & $\begin{array}{l}.178 * * \\
(.057)\end{array}$ & $\begin{array}{l}.040 \\
(.055)\end{array}$ \\
\hline & & $\begin{array}{l}.142^{* *} \\
(.018)\end{array}$ & $\begin{array}{l}.211^{* *} \\
(.023)\end{array}$ & & \\
\hline $\begin{array}{l}.177^{* *} \\
(.024) \\
.121 * * \\
(.025)\end{array}$ & & $\begin{array}{l}.174 * * \\
(.024) \\
.110^{* *} \\
(.025)\end{array}$ & & $\begin{array}{l}.169 * * \\
(.030) \\
.140 * * \\
(.032)\end{array}$ & \\
\hline & $\begin{array}{l}.209 * * \\
(.036) \\
.154 * * \\
(.037)\end{array}$ & & $\begin{array}{l}.298^{* *} \\
(.033) \\
.234^{* *} \\
(.034)\end{array}$ & & $\begin{array}{l}.058^{*} \\
(.028) \\
.060 \\
(.029)\end{array}$ \\
\hline $\begin{array}{l}.172 * * \\
(.050)\end{array}$ & $\begin{array}{l}.171^{* *} \\
(.074)\end{array}$ & $\begin{array}{l}.131^{*} \\
(.052)\end{array}$ & $\begin{array}{l}.256^{* *} \\
(.070)\end{array}$ & $\begin{array}{l}.156 * \\
(.064)\end{array}$ & $\begin{array}{l}.082 \\
(.053)\end{array}$ \\
\hline & $\begin{array}{l}.338 * * \\
(.004)\end{array}$ & & $\begin{array}{l}.337 * * \\
(.004)\end{array}$ & & $\begin{array}{l}.241^{* *} \\
(.004)\end{array}$ \\
\hline & $\begin{array}{l}.392 * * \\
(.053) \\
.497 * * \\
(.116)\end{array}$ & & $\begin{array}{l}.276^{* *} \\
(.054) \\
.001 \\
(.181)\end{array}$ & & $\begin{array}{l}.297 * * \\
(.072) \\
.147 \\
(.101)\end{array}$ \\
\hline
\end{tabular}

Sub samples

(8) raised with own-birth

siblings $(\mathrm{N}=526,435)$

Own-birth children

(9) Baseline results:

( $\mathrm{N}=940792,91932)$

Other samples:

(10) raised with adopted

siblings ( $\mathrm{N}=412,405)$

(11) with bio siblings adopted out $(\mathrm{N}=193,180)$

Notes: Standard errors are shown in parentheses; * indicates significance at 5\% level, and ** at $1 \%$ level; All specifications include controls for the child's gender, 4 birth cohort dummies for the child, 8 birth cohort dummies for biological/adoptive father/mother and 25 region dummies of where the biological/adoptive family lived in 1965; Also sample sizes are shown in parentheses. For instance, in row $2(\mathrm{~N}=638,602)$ means that number of observations is 638 in columns 1-4 (for university education) and 602 in columns 5-6 (for income). 